\title{
Land use, farm businesses and environmental policy in the Lake Taupo catchment
}

\author{
B. THORROLD ${ }^{1}$, J. FINLAYSON ${ }^{1}$, G. LAMBERT ${ }^{1}$, S. LEDGARD ${ }^{1}$, D. SMYTH ${ }^{2}$, \\ I. TARBOTTON ${ }^{1}$, D. SMEATON ${ }^{1}$ and R. WEBBY ${ }^{1}$ \\ ${ }^{1}$ AgResearch Ruakura, Private Bag 3123, Hamilton \\ ${ }^{2}$ Curnow Tizard Ltd., P.O. Box 795, Hamilton \\ bruce.thorrold@agresearch.co.nz
}

\begin{abstract}
Lake Taupo is a high quality lake in the centre of the North Island, New Zealand. Local government aims to control nitrogen $(\mathrm{N})$ inputs into the lake to preserve lake water quality. In this paper we discuss the implications of this policy for land use and farm management in the Lake Taupo catchment. To do this we used a case study approach, based on a typical farm, to examine the effects of stocking density and management system on farm cash surplus, farm capital value and nitrate leaching. The study showed that intensification of land use is a profitable option for farmers and any restrictions on land use in the Lake Taupo catchment will have large effects on the profitability and value of existing farm businesses. Farm systems can be adapted to reduce $\mathrm{N}$ leaching, however the options that we studied all resulted in a decrease in farm cash surplus. Further evaluation and experimentation on new systems is required. Rules that control farm activities in an attempt to control $\mathrm{N}$ leaching may not result in the gains desired owing to legitimate adjustments that farmers may make to re-optimise their farm business.
\end{abstract}

Keywords: economic evaluation, farm systems, modelling, nitrate leaching, water quality

\section{Introduction}

Lake Taupo is a high quality lake in the centre of the North Island, New Zealand. Surveys of public opinion (Stewart et al. 2000) have confirmed the importance of many lake features including 'Clean, clear water' and 'Natural, unspoilt character' to the local residents. The history of catchment development and lake monitoring has been reviewed by Edgar (1999) and Vant \& Huser (2000) and is summarised in the following section. Prior to European settlement the catchment was mainly covered in tussock grassland and native forest. In the 1970 s, water quality issues became apparent with erosion of streams and gullies in the land recently cleared for pastoral use and discharges from urban septic tanks and sewage. The Waikato Valley Authority, central government and landowners acted on these issues with extensive stream bank retirement and planting and the provision of sewage treatment schemes in many settlements. In the 1990s, public surveys and lake monitoring revealed new issues with water quality. Public surveys indicated that the incidence of nuisance weed and slime growth near the lakeshore was of concern (Stewart et al. 2000). In the lake, nitrogen (N) and algae levels were increasing and a small decrease in lake clarity was also measured. Nitrogen concentrations in streams flowing into the lake were also found to have increased since the time of pastoral development in the 1970s. All these measures indicated that the quality of the lake, although still excellent, was declining. Furthermore, future increases in urban population and farm intensity were likely to increase nitrogen inputs into the lake putting further pressure on lake water quality.

In response to this situation, Environment Waikato (the Regional Council responsible for the lake) launched a public process in May 2000 to produce a variation to its Regional Plan aimed at controlling $\mathrm{N}$ inputs into the lake and preserving lake water quality. One option for controlling the amount of $\mathrm{N}$ entering the lake is to control land use and farm management practices. The influence of land use on $\mathrm{N}$ losses is illustrated in the initial nitrogen budget for the lake calculated by Vant \& Huser (2000), based largely on stream data collected in the 1970s. This is summarised in Table 1, and shows that $\mathrm{N}$ losses from pasture land are estimated to be higher than from forestry or native vegetation. Calculations (Table 1) using the OVERSEER ${ }^{\circledR}$ nutrient balance model (Ledgard et al. 2001) suggested that the estimates made from the 1970 s data may underestimate the losses from pastoral land owing to lags between land use change and stream response. More recent stream $\mathrm{N}$ data, collected by Environment Waikato (B.Vant, pers. comm.), showing increased N concentration in streams draining pastoral catchments support this interpretation. Table 1 shows that high $\mathrm{N}$ losses can occur under dairy farming, and further intensification of dry-stock operations on existing farms also poses risks of increased $\mathrm{N}$ inputs into the lake. 
In December 2000, we met with farmers in the catchment to discuss their concerns about the impacts of land use regulations on their businesses. They identified concerns about the profitability, capital value and flexibility of their farming operations. The aim of this project was to assess the impacts of restrictions on land use and management practice on farm profitability and capital value. In this paper we discuss the results of this work and the implications for land use, farm management and policy development in the Lake Taupo catchment.

\section{Methods}

In this project we used a case study approach, drawing on local farmer knowledge to describe a 'typical' farm for the catchment. This base farm was assumed to be a 285-ha, moderately intensive, sheep and beef farm carrying 12 su/ha and of suitable contour for dairy conversion. Prices and returns for the 1999/ 2000 financial year were used. A debt of \$275 000 was assigned to the farm as a starting point for comparison with other systems. We then looked at the future options available to the base farm. These included de-stocking, intensification of the sheep-beef farming system or conversion to dairying. The farm systems that were analysed are detailed in Table 2. Debt levels, operating costs and income were altered to reflect the transition from the base farm to future options. For example, changing from 12 to $8 \mathrm{su} /$ ha allows $\$ 500 /$ ha of debt to be retired as livestock are sold and less fertiliser is required for $4-5$ years. This compares with increasing to $16 \mathrm{su} / \mathrm{ha}$ where $\$ 680 / \mathrm{ha}$ of additional debt is required to purchase stock, apply capital fertiliser and improve fences, yards and water reticulation. The costs of dairy conversion, including dairy company shares, are higher again. Debt servicing was incorporated based on a table mortgage at $9 \%$ over 20 years.

Farm cash surplus, defined as net return after interest, principal and management wages but before depreciation, capital investment, dividends and tax, was calculated. Farm performance was modelled for sheep-beef farms using Stockpol and for dairy farms using Udder. This approach allowed re-optimisation
Table 1 Estimates of $\mathrm{N}$ losses from different land use.

\begin{tabular}{lcc}
\hline Land use & $\begin{array}{c}\mathrm{kg} \mathrm{N} / \mathrm{ha} / \text { year } \\
\text { in streamflow }\end{array}$ & $\begin{array}{c}\mathrm{kg} \mathrm{N} / \mathrm{ha} / \mathrm{year} \\
\text { leached below } \\
\text { root zone }\end{array}$ \\
\hline Bare and tussock land & 2 & - \\
Native forest & 2.5 & - \\
Pine forest & 2.5 & - \\
Pasture (sheep-beef) & 5 & 14 \\
Pasture (dairy) & - & 49 \\
\hline${ }^{\text {'from Vant and Huser (2000) }}$ & & \\
${ }^{2}$ from Ledgard et al. (2001) & & \\
\hline
\end{tabular}

Table 2 Farm systems used in future options analysis.

\begin{tabular}{|c|c|c|c|}
\hline arm system & Stock type & Stocking rate & Term debt (\$) \\
\hline urrent & $\begin{array}{l}\text { Sheep-Beef breeding } \\
\text { and finishing }\end{array}$ & 12 su/ha & 275000 \\
\hline ow intensity & $\begin{array}{l}\text { Sheep-Beef breeding } \\
\text { and store stock sales }\end{array}$ & 8 su/ha & 132000 \\
\hline ligh intensity & $\begin{array}{l}\text { Sheep breeding } \\
\text { and finishing }\end{array}$ & & \\
\hline & Bull finishing & $16 \mathrm{su} / \mathrm{ha}$ & 470000 \\
\hline Convert to dairy & Dairy & $\begin{array}{c}2.7 \mathrm{cows} / \mathrm{ha} 800 \mathrm{~kg} \\
\mathrm{MS} / \mathrm{ha}\end{array}$ & 1775000 \\
\hline
\end{tabular}

of management systems in response to imposed management constraints.

\section{Policy options and impacts on farms}

In early discussions with the public, Environment Waikato identified four options for lake management which link future lake quality with land use and management (Table 3). The methods for achieving these options are yet to be specified, but might include regulation, incentives and education.

Capital values for each farm system were assessed under two scenarios. Firstly, values for each system in year 2000, prior to the announcement of the Environment Waikato policy initiative, were assessed based on sales in the district during this time. This showed that farm valuation increased with increasing productive capacity. The valuation for forestry was taken as the price that forestry interests were willing to pay for land elsewhere, as there were no local sales.

Secondly, the capital value of each farm was forecast under the Option 3 scenario where the farm would be

Table 3 Summary of the options for lake management as described by Environment Waikato and consequences for human activity in the Lake Taupo catchment.

\begin{tabular}{lll}
\hline Option & Consequences for lake & Consequences for human activity \\
\hline Option 1 & Restore lake quality to pristine standards & Removal of most human activity from catchment \\
Option 2 & Maintain current water quality & Reduce inputs of N from all human activity \\
Option 3 & Accept some decline in lake water quality & Cap current inputs of N into the lake \\
Option 4 & Accept substantial decline in lake water quality. & No controls on land use and management \\
\hline
\end{tabular}


restricted from further pastoral intensification. In the absence of farm sales under this type of restriction, forecasting valuations posed a challenge. The method adopted was based on comparisons of the ratio of rental income to capital value for commercial properties in different parts of Hamilton. A property with good prospects for future income growth and capital gain was found to have a rental return of $9 \%$ on capital value compared to a rental return of $12 \%$ on capital value for a similar property in an area with poorer future prospects. This equates to a $25 \%$ lower capital value for the property with the same current income but less future potential for income growth and capital gain. Under Option 3, farmers are able to maintain current income levels, but face future uncertainty in their ability to increase income and the capital growth of their properties. We argue that applying the commercial property analogy suggests that a loss of capital value of about $25 \%$ would follow restrictions on pastoral intensification, given the possible consequences of restriction on future income growth and capital gains.

The consequences of the different Options were assessed for the base farm of $12 \mathrm{su} / \mathrm{ha}$ and are summarised in Figure 1. Under Option 1, farmland would need to convert to forest. This will lead to reduced land value and require funding of the cash flow deficit that accompanies conversion to forestry. Owing to large differences in cashflow timing between forestry conversion and farming, we have not attempted to calculate an equivalent annual cash surplus for this conversion. In order to maintain current lake quality (Option 2) it is likely that some level of reduction in $\mathrm{N}$ output from current farmland will be required. Based on discussions with Environment Waikato staff, we assumed a $25-30 \%$ reduction in $\mathrm{N}$ output as a possible target (B. Vant, pers. comm.). This corresponds to the $12 \mathrm{su} / \mathrm{ha}$ farm decreasing in intensity to $8 \mathrm{su} / \mathrm{ha}$, with a consequent drop in capital value, and a reduction in income leading to an annual cash deficit. Under Option 3 , cash surplus will be maintained at current levels in the short-term, but farm capital value falls from $\$ 1150000$ to $\$ 829000$. Under Option 4, intensification is possible (the current situation), and Figure 1 shows the results of both dairy conversion (Option 4D) and intensifying to $16 \mathrm{su} /$ ha (Option 4S). The sheep-beef intensification leads to increases in both cash surplus and farm value. The dairy conversion option leads to a large increase in farm value (including dairy company shares). However, the debt servicing associated with the conversion means that the annual cash surplus of the dairy farm is slightly below that of the $16 \mathrm{su} / \mathrm{ha}$ sheep-beef farm at the assumed levels of production and prices.
Figure 1 Effect of changing land use on farm capital value and cash surplus for the base 12 su/ha farm. Scenarios include the situation prior to May 2000 (Current), conversion to forestry (Option 1), restricted to low intensity sheep-beef farming (8 su/ha, Option 2), restricted to current intensity (Option 3 ) and following conversion to intensive sheep-beef farming (16 su/ha, Option 4S) or dairy farm (Option 4D). Both Option 4 situations have no restrictions on further development.

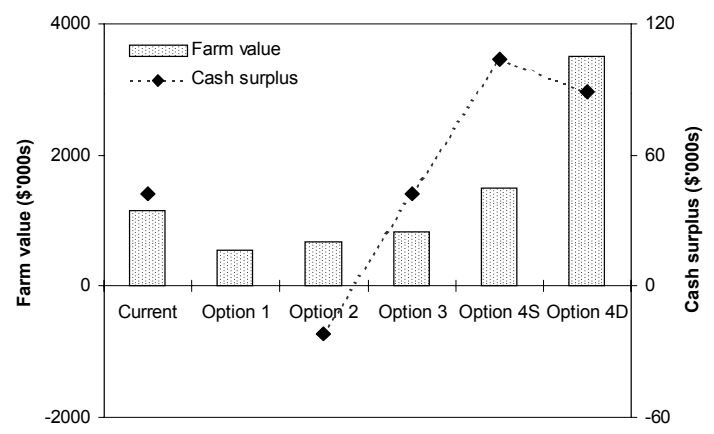

Figure 2 The effect of a range of dairy production systems on annual cash surplus and $\mathrm{N}$ leached. Systems all have the same base pasture growth with addition of $150 \mathrm{~kg}$ fertiliser N/ha/yr with no restrictions $(150 \mathrm{~N}), 50 \mathrm{~kg}$ fertiliser N/ha/yr with no restrictions (50N), $50 \mathrm{~kg}$ fertiliser $\mathrm{N} /$ ha/yr with cows wintered off (Winter) and no $\mathrm{N}$ fertiliser with bought-in maize silage fed at $500 \mathrm{~kg} \mathrm{DM} / \mathrm{ha} / \mathrm{yr}$ (Maize).

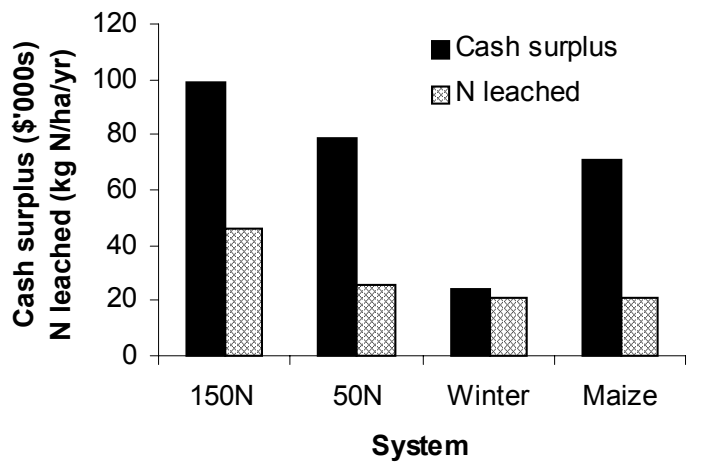

The analysis shows clearly that the imposition of restrictions on land use would be expected to have large effects on the cash surplus and capital value of farm businesses.

\section{Adjustment to farm systems}

Based on our understanding of the nitrogen cycle it is apparent that opportunities do exist to reduce $\mathrm{N}$ leaching from pastoral systems by changes in management 
practice (Ledgard et al. 2001). These options include; reducing $\mathrm{N}$ losses in winter by removing animals from pasture, reducing $\mathrm{N}$ in the diet by feeding low $\mathrm{N}$-high energy feeds such as maize silage, changing from beef to sheep stock units and reducing $\mathrm{N}$ fertiliser use.

The effects of some of these options were examined by using the farm systems models to optimise cash surplus under a number of constraints. Leaching was calculated from the OVERSEER ${ }^{\circledR}$ nutrient budget model as described by Ledgard et al. (2001).

For the standard dairy farm the options investigated were

1. Reduce $\mathrm{N}$ fertiliser use from 150 to $50 \mathrm{~kg} \mathrm{~N} / \mathrm{ha} /$ year.

2. Eliminate $\mathrm{N}$ fertiliser use and replace the $\mathrm{N}$ generated feed with $500 \mathrm{~kg} \mathrm{DM} / \mathrm{ha}$ bought in as maize silage.

3. Reduce $\mathrm{N}$ fertiliser use to $50 \mathrm{~kg} \mathrm{~N} / \mathrm{ha}$ and winter all cows off the farm from 1 June to 31 August.

Each system had different optimum stocking rate and milk solids production. Reducing $\mathrm{N}$ fertiliser use from 150 to $50 \mathrm{~kg} \mathrm{~N} /$ ha reduced cash surplus, and had a large effect on $\mathrm{N}$ leaching (Figure 2). Replacing the $50 \mathrm{~kg} \mathrm{~N}$ fertiliser/ha with maize silage further reduced cash surplus owing to the higher cost of maize silage compared to $\mathrm{N}$-boosted grass. Further gains in $\mathrm{N}$ leaching were obtained owing to the greater efficiency of $\mathrm{N}$ cycling in this system. The wintering off option was expected to produce large benefits in $\mathrm{N}$ leaching. However the results showed that, compared to other options, there was little impact on $\mathrm{N}$ leaching while farm profitability was severely reduced owing to the costs of wintering off and increased cow numbers. This result came about from the choices made to optimise farm profit under this constraint. The system used an increased stocking rate and grazed the farm out in autumn to optimise the use of the pasture made available by having the cows off in winter. However, the high autumn utilisation led to substantial leaching of the $\mathrm{N}$ deposited as urine in the autumn.

A similarly interesting result was seen in comparing a bull beef system with a sheep-beef system (data not presented). In theory the sheep-beef system would have lower $\mathrm{N}$ leaching losses owing to the more dilute $\mathrm{N}$ concentration of sheep urine compared to cattle urine. However, with the same pasture growth for both systems, it was possible to carry a higher stocking rate on the sheep-beef farm owing to the improved match of pasture supply and demand. This increased pasture utilisation and the amount of $\mathrm{N}$ cycled through the urinary pathway in the sheep-beef system, cancelling out the gains made from reducing the cattle to sheep ratio.

\section{Conclusions}

A fundamental aim of the Lake Taupo variation is to control $\mathrm{N}$ inputs into the lake. The work shows that intensification of land use is a profitable option for farmers in the Lake Taupo catchment. This suggests that controls on land use will be required to prevent further intensification of pastoral farming with increases in $\mathrm{N}$ leaching. It appears these controls will place substantial costs onto farmers, suggesting that voluntary adoption of restrictions is unlikely without substantial financial support.

By changing farm management practices it is possible to substantially reduce $\mathrm{N}$ leaching, although in all of the options we studied this reduced farm cash surplus. Further research is required to evaluate and field-test management options.

Measuring $\mathrm{N}$ leaching is difficult and expensive, so an alternative to monitoring is to regulate farm management practices. By using the simulation models we have demonstrated that management rules require systems level analysis to ensure that the desired reductions in $\mathrm{N}$ leaching will occur.

\section{ACKNOWLEDGEMENTS}

The authors acknowledge the important contribution made to this work by farmers in the Lake Taupo catchment, in particular Bob Cottrell, Sue Yerex, Richard Fox and Graham Law. This work was funded by the Foundation for Research, Science and Technology.

\section{REFERENCES}

Edgar, N.B. 1999. Land use in the Taupo catchment, New Zealand. New Zealand Journal of Marine and Freshwater Research 33: 375-383.

Ledgard, S.F.; Thorrold, B.S.; Petch, R.A.; Young, J. 2001. Use of OVERSEER ${ }^{\circledR}$ as a tool to identify management strategies for reducing nitrate leaching from farms around Lake Taupo. In: Precision Tools for Improving Land Management. Ed. L.D. Currie. Occasional Report No. 14. Fertilier and Lime Research Centre, Massey University, Palmerston North. (in press)

Stewart, C.; Johnston, D.; Rosen, M.; Boyce, W. 2000. Public involvement in environmental management of Lake Taupo: preliminary results of the 1999 survey. Institute of Geological and Nuclear Sciences Limited science report 2000/7. 16p.

Vant, B.; Huser, B. 2000. Effects of intensifying catchment land use on the water quality of Lake Taupo. Proceedings of the New Zealand Society of Animal Production 60: 262-264. 